\title{
Kaksi tapaa opettaa suomea vieraana kielenä - Johannes Aavikin (1902) Praktilik Soome keele õpetus ja Béla Györffyn (1939) Gyakorlati finn nyelvkönyv
}

\author{
MARJUT VEHKANEN \\ Helsingin yliopisto
}

Tiivistelmä. Suomi vieraana kielenä -oppikirjoja on kirjoitettu reilusti yli sadan vuoden ajan eri puolilla maailmaa, erilaisia tarkoitusperiä varten. Ensimmäisinä suomesta vieraana kielenä kiinnostuivat Viron ja Unkarin yliopisto-opetukseen perehtyneet asiantuntijat. Tarkastelen artikkelissani kahta viime vuosituhannella ilmestynyttä suomen sukukielen - viron ja unkarin - puhujille suunnattua S2-oppikirjaa. Käsittelen artikkelissani kieliopin roolia ja sen esittämistapoja näissä kirjoissa sekä kirjojen pedagogisia ratkaisuja, taustana S2-opetuksen historia. Muodostan tulkintojeni ja havaintojeni avulla kokonaiskäsityksen niistä kieliopin kuvausten eri ratkaisumalleista, joita virolainen tai unkarilainen oppikirjankirjoittaja on halunnut käyttää opettaessaan suomea kohderyhmilleen.

Avainsanat: suomi vieraana kielenä; S2-kieliopin opetus; S2-oppikirjan pedagogiset ratkaisut; viro ja unkari lähtökielinä 


\section{Johdanto}

Artikkelini tarkastelun kohteina ovat Johannes Aavikin (1902) Praktilik Soome keele õpetus ja Béla Györffyn (1939) Gyakorlati finn nyelvkönyv 'Käytännön suomen oppikirja'. Ne sisältyvät väitöskirjani tutkimusaineistoon 50 muun vuosina 1866-1953 ilmestyneen S2-oppikirjan ohella (Vehkanen 2015: 14). Kirjat ovat aineiston ainoat vironkielisille ja unkarinkielisille opiskelijoille kirjoitetut suomi vieraana kielenä -oppikirjat. Oppikirjojen rinnakkainen tarkastelu on haasteellista, sillä kirjat ilmestyivät eri ajankohtina etäällä toisistaan, kirjojen käyttäjäryhmät ovat erilaiset ja myös kirjoittajien tausta ja suhde suomen kielen opetukseen on erilainen. Näistä eroavaisuuksista huolimatta mielestäni on hyödyllistä ja antoisaa tarkastella kielioppien roolia mainituissa suomen sukukielen oppikirjoissa, vertailla kirjoittajien kirjojen ilmestymisajankohtina valitsemia kieliopillisia ja pedagogisia ratkaisumalleja ja niissä tapahtuneita mahdollisia muutoksia. Selvitän, kuinka kirjojen erilaiset käyttötarkoitukset säätelevät näissä oppikirjoissa kieliopin opetuksen sisältöä ja edellyttävät erilaisia kielenopetuksellisia ratkaisuja. Vertailen, millaisia kieliopin kuvaamisen malleja kirjoittajat lukijoilleen tarjoavat, heijastaen niitä S2-opetuksen historiaan.

Suomen kielestä käytän tässä yhteydessä suomi vieraana kielenä -termiä, sillä tutkittavat suomen kielen oppikirjat ovat olleet käytössä Virossa ja Unkarissa eli opiskeltavasta kielestä erillään, eivät Suomessa suomenkielisessä ympäristössä (Elomaa 2009: 19; Suni 2008: 30-31). Termillä kielioppi tarkoitan artikkelissani kielenopetusta varten laadittua didaktista kielioppia, jonka materiaalia käyttävät oppikirjan laatijat, opettajat ja oppikirjaa käyttävät opiskelijat (Elomaa 2009: 19-20, 61). Vierasta kieltä opiskeltiin 1900-luvun alussa sata vuotta vallalla olleen kielioppi-käännösmenetelmän avulla, jossa kielioppi on kirjan sisällön punaisena lankana. Keskeistä tässä menetelmässä on myös tekstin kääntäminen, joka edelleen kuuluu opetuksen tavoitteena oleviin käytännön taitoihin (Richards \& Rodgers 2001: 5-7; Ingo 1990: 67-72). 
Jo ensimmäiset suomen kieliopit kirjoitettiin muunkielisiä aikuisopiskelijoita varten. Eskil Petraeuksen (1593-1657) Linguae Finnicae brevis institutio (1649) oli tarkoitettu suomen alkeisoppikirjaksi latinantaitoisille ulkomaalaisille virkamiehille, papeille ja munkeille, joiden suomen kielen taidot olivat puutteelliset ja jotka työtehtävissään tarvitsivat suomen kieltä (A. Hakulinen 2008: 268-269; Kieli ja sen kieliopit 1994: 28). Opetukseen kuului siis suomi toisena ja vieraana kielenä -näkökulma. Suomessa suomen kieli tuli koulujen opetukseen kahdessa vaiheessa: ensin opetettavaksi kieleksi muiden vieraiden kielten joukossa ja vasta sen jälkeen opetettavaksi äidinkieleksi.

Suomen kielen ensimmäisissä kieliopeissa on kontrastiivinen ote: kuvattavaa kieltä verrataan latinaan. Kieliopeissa on latinan oppikirjoista mukailtuja sääntöjä, joihin suomen kielen esimerkit on sovitettu. Näin on muun muassa Petraeuksen kieliopissa. Muunkielisten opiskelijoiden tuli opiskella suomea latinan kautta, sillä siten heidän uskottiin ymmärtävän latinan kielioppikategorioiden avulla suomen kieliopin vastaavat muodot (Vihonen 1978: 29-31; Wiik 1989: 12; Kieli ja sen kieliopit 1994: 28). Bartholdus G. Vhaëlin (1667-1723) kirjoittama Grammatica Fennica (1733) poikkeaa kuitenkin edeltäjistään siinä, että se ei tukeudu latinan kieliopin malliin, vaan kuvaa suomen kielen ominaislaatua. Kirjoittaja käyttää kielioppinsa kielenä latinaa ja esimerkkiensä kuvauksessa sen lisäksi suomea ja ruotsia (Vhaël 1733: 33).

Kun Aavikin (1902) oppikirja ilmestyi, Suomessa elettiin autonomian ajan loppupuolta, kun taas Györffyn (1939) oppikirjan ilmestyessä Suomessa alkoi talvisota. Aavikin oppikirja tukeutui suomalaisten oppikirjojen sisältöihin (Kallio 1887, 1904; Setälä 1880) ja kielioppikäännösmenetelmän mukaiseen pedagogiikkaan, kun taas Györffyn kirjan aikoihin suomi vieraana kielenä -oppikirjoja kirjoitettiin jo monenlaisiin käyttötarkoituksiin kuten tänäänkin: yliopistojen ja kielikurssien käyttöön, historiallisten ja sosiokulttuuristen tapahtumien synnyttämään oppikirjatarpeeseen (kansainvälistyminen, matkailu, sodat, Neuvostoliiton synty) sekä eri opetusmenetelmien ja opetustekniikan kehittymisen mukanaan tuomiin oppimateriaalitarpeisiin 
KAKSI TAPAA OPETTAA SUOMEA VIERAANA KIELENÄ

(fraasikirjat, kansainväliset kielikoulut; Tanner 2012: 31; Vehkanen 2015: 48-55).

\section{Tutkimusaineisto ja menetelmä}

Johannes Aavikin (1902) Praktilik Soome keele õpetus on julkaistu suomalaisessa Yrjö Weilinin kustantamossa Suomessa ja Béla Györffyn (1939) Gyakorlati finn nyelvkönyv reilut kolmekymmentä vuotta myöhemmin Unkarissa historiallisesti, kulttuurisesti ja maantieteellisesti erilaisessa kontekstissa ja erilaiselle kohderyhmälle (Vehkanen 2015: 59). Tarkastelen artikkelissani tapaustutkimuksena näitä kahta toisistaan etäällä ja eri ajankohtina tuotettua S2-oppikirjaa ja pyrin niiden sisältöjen ja mahdollisten opetuksellisten muutosten avulla avaamaan kirjoittajien kirjoittamisen lähtökohtia.

Tutkimus perustuu oppikirjojen sisältöjen vertailuun ja niiden analysointiin. Artikkelissani luokittelen ja vertailen aineiston kielioppien rooleja ja esittämistapoja tutkittavissa oppikirjoissa sekä niiden pedagogisia ratkaisumalleja. Menetelmäni on tulkintaan ja päättelyyn perustuva laadullinen aineistolähtöinen sisällönanalyysi, jossa etenen aineistoni havainnoista kohti laajempaa kokonaisuutta. Näin toivon pystyväni muodostamaan kiinnostavan uuden näkökulman tutkittujen oppikirjojen tapaan opettaa suomea vieraana kielenä (Tuomi \& Sarajärvi 2013: 95-96, 108-109, 123-124; Hirsjärvi ym. 2013: 126-128).

\section{Kaksi taustaltaan erilaista S2-oppikirjan kirjoittajaa}

Sanotaan, että oppikirjojen kirjoittajat jäävät usein kirjojensa varjoon. Vaikka oppikirjalla on erityinen asema kirjana, kirjoittajat saatetaan tuntea vain asiantuntijapiireissä. Ehkä vain harvat oppilaat ja opettajat tietävät, keitä heidän oppikirjojensa kirjoittajat ovat (Långström 1997: 20-21). Tässä tutkittujen oppikirjojen kirjoittajien kohdalla tämä väittämä ei taida pitää paikkaansa. Aavik oli Virossa tunnettu 
kulttuuripersoona ja suomen kielen vaalija, Györffy taas pappina teologian opiskelijoille tunnettu henkilö.

Yliopistolliseen ja kielikoulujen kielenopetukseen suunnattuja oppikirjoja ilmestyy 1900-luvulla, mutta tällöin uutena oppikirjatyyppinä alettiin toimittaa myös sotilaiden suomen kielen opetukseen tarkoitettuja oppikirjoja. Kansainväliseen kanssakäymiseen ja matkailuun suunnattuja suomen kielen keskustelukursseja alkoi niin ikään ilmestyä ensimmäisen maailmansodan jälkeen. Väitöskirjani aineistossa on yhteensä 26 aikuisille kirjoitettua oppikirjaa vuosilta 1902-1953. Rakenteiltaan ja opetusmetodeiltaan perinteisiä oppikirjoja kirjoitettiin edelleen niin yliopiston opiskelijoille kuin muillekin opiskelijaryhmille. Perinteisten oppikirjojen kirjoittajia aineistossani ovat Johannes Aavik (1902), Eero Neuvonen (1935), Björn Collinder (1941), Wolmar Bergh (1940) ja Béla Györffy (1939). He kirjoittivat oppikirjoja joko maanmiehilleen tai johonkin tiettyyn tarpeeseen kuten Collinder sotilashenkilöille (Vehkanen 2015: 42-43).

\subsection{Johannes Aavik, viron kielen uudistaja, kaunokirjallisuuden kääntäjä ja tietokirjailija}

Johannes Aavik (1880-1973) oli opiskellut suomea vapaaehtoisesti jo koulussa lukuisten muiden kielten (latina, kreikka, saksa, ranska) ohella ja valmistunut filosofian kandidaatiksi Helsingin yliopistosta. Hänen aineyhdistelmässään olivat suomen kieli ja sukukielet, romaaninen filologia ja romaaninen kirjallisuus sekä venäjän kieli ja kirjallisuus. Hän oli siis erittäin lahjakas, monia eri kieliä hallitseva kielimies ja filologi, mitä todisti myös hänen tuleva työuransa. Valmistumisensa jälkeen hän toimi hyvin monenlaisissa tehtävissä: opetti 1910-1911 Krimillä kymnaasissa ranskaa, toimi Tartossa sekä lehtimiehenä että kauppakoulun viron ja ranskan opettajana ja edelleen Kuressaaressa vuosina 19191926 viron ja latinan opettajana. Tämän jälkeen Aavik toimi viron kielen lehtorina Tarton yliopistossa 1926-1934, ja vuosina 1934-1940 hän oli maansa opetusministeriön koulujen ylitarkastaja. Hänet erotettiin 
virkatehtävistään vuonna 1940 ensimmäisen neuvostomiehityksen aikana. Vuosina 1940-1944 Aavik käänsi ja toimitti oppikirjoja synnyinmaassaan, mutta pakeni 1944 Ruotsiin. Siellä hän jatkoi viron kielen uudissanojen luomista kuolemaansa asti. (Remes 2010a: 58, 61, 63-64; Remes 2010b; R. Grünthal 2009: 236)

Helsingin yliopistossa suorittamansa tutkinnon ansiosta Aavik oli syvällisesti perehtynyt suomen kieleen. Hänestä tuli viron kielen uudistaja sekä ansioitunut myös suomalaisen kirjallisuuden, kuten esimerkiksi Juhani Ahon tuotannon virontaja. Viron kielen uudistajana hän lainasi sanoja nimenomaan suomen kielestä ja teki uudistusehdotuksia myös suomen kielen morfologia esikuvanaan. Hänen ehdottamiaan suomen kielen lainasanoja lasketaan olevan viron kielessä noin 800. Aavik toivoi, että virolaiset perehtyisivät suomen kieleen, jotta he sen avulla voisivat havaita viron kielen heikkoudet suomen kieleen verrattuna. Kirjansa esipuheessa hän sitten kertookin laatineensa tätä tarkoitusta varten suomen kielestä kiinnostuneille tutkimukseni kohteena olevan Praktilik Soome keele õpetus -oppikirjan (1902). (Aavik 1902: esipuhe; Remes 2010b: 58-59, 65) Aavik (1902: V) mainitsee esipuheessaan, että kiinnostus suomen kieltä kohtaan oli kirjan ilmestymisen aikoihin Virossa lisääntynyt, ja toivoo kirjalle laajaa käyttäjäkuntaa. Oppikirjan sisältö perustuu lähtö- ja kohdekielen vertailuun, ja kirja on opetuslähtökohdiltaan kaksikielinen.

Viron kielen uudistajana Aavik suuntasi kirjansa viron kielen kehittämisestä kiinnostuneille. Tästä näkökulmasta suomen ja viron kielen vertaileva käsittelytapa tuntuu luontevalta ja odotuksenmukaiselta. Kirjan nimen ensimmäinen sana on kuitenkin praktilik 'käytännöllinen', ja kirjan esipuheessa puhutaan myös tämän kirjan opetussisällön käytännöllisyydestä. Edellä kuvattu asetelma antaa kirjan käyttötarkoituksesta hieman ristiriitaisen kuvan.

Aavikilla on kirjansa lähteinä sekä Suomen ruotsinkielisille kouluille tarkoitetut Aukusti Kallion $(1887,1890,1904)$ oppikirjat että Emil Nestor Setälän (1890) lauseoppi. Suomenkielisen asun on tarkastanut tuolloinen filosofian kandidaatti Lauri Kettunen. Lähdekirjallisuus ja 
kielentarkistajan sekä kirjoittajan oma tausta vahvistavat käsitystäni siitä, ettei kirja olisi suunnattu kaikille suomen kielestä kiinnostuneille vasta-alkajille. Oppikirja on tarkoitettu, kuten Aavik esipuheessaan toivoikin, viron kielen kehittämisestä ja suomen kielestä kiinnostuneille ja suomen kieliopin jo entuudestaan hallitseville vironkielisille suomen kielen opiskelijoille (mts. V).

\subsection{Béla Györffy S2-oppikirjan kirjoittajana}

Tohtori Béla Györffy (1892-1951) oli unkarilainen luterilainen pappi, kansanvalistaja, joka oli opiskellut ulkomailla myös lääketiedettä ja toimi Unkarin maaseudulla niin kutsuttuna kylätohtorina (Béla Györffyn henkilötiedot). Hän kirjoitti oppikirjan Gyakorlati finn nyelvkönyv (1939) maansa luterilaisille teologian opiskelijoille. Györffyllä ei ilmeisesti ollut suomen kielen yliopisto-opiskelutaustaa. Sen seikan ei kuitenkaan tarvinnut olla este oppikirjan laadintaan, sillä juuri papit ovat historian saatossa olleet niin Suomessa kuin muuallakin kansojensa valistajia. Papit kirjoittivat kirkollisen virkansa ohella Suomessakin suomen kielen oppikirjoja ja jopa suomen kieltä käsittelevän väitöskirjankin (Corander 1853; Vehkanen 2015: 37-38). Györffy ei ollut filologi, vaan pappi ja kylätohtori. Hänen kohdallaan jää toistaiseksi arvoitukseksi, missä ja miten hän oli oppinut suomen kielen.

Unkarissa kiinnostus sukulaiskieltä suomea kohtaan oli voimakasta jo 1800-luvulla. Tuolloin ilmestyi suomen ja unkarin kielen vertailevia kuvauksia (Kállay 1844; Hunfalvy 1853), suomenkielisiä lukemistoja unkarilaisille (Hunfalvy 1861; Budenz 1873; Szinnyei 1895) sekä suomen kielioppeja unkariksi (Fabián 1859; Budenz 1873). Myös 1900-luvun taitteessa Unkarissa oli monta merkittävää suomen kielen harrastajaa. Heitä olivat esimerkiksi Budapestin yliopiston suomalais-ugrilaisen laitoksen esimies (1893-1931) ja Unkarin tiedeakatemian jäsen József Szinnyei sekä häntä aikaisemmin laitoksen esimiehenä toiminut professori József Budenz (1872-1893). Molemmat tiedemiehet vierailivat Suomessa ja kirjoittivat runsaasti suomen kieleen liittyviä teoksia, Budenz 
esimerkiksi suomen kieliopin Finn nyelvtan (1873) (Karlsson 2000: 70-71; Heikkinen 1981).

Györffyn kirja ei kuvauksessaan nojaa kielisukulaisuuteen kuten Aavikin kirja. Myös uskonnollisten aiheidensa puolesta se poikkeaa Szinnyein ja Budenzin sekä muiden aikalaisten S2-oppikirjoista. Kirjoittajan erityistehtävänä oli tuottaa Unkarin luterilaisille teologian opiskelijoille oppikirja, joka olisi aiheiltaan käyttäjiä ajatellen sopivan uskonnollissävytteinen ja sisällöltään sopiva suomen kielen ja kulttuurin opetukseen. Toisin kuin Aavik, hän ei laajalti vertaile unkarin ja suomen kieltä toisiinsa; tämä pedagoginen ratkaisu johtunee siitä, että hän taustaltaan oli käytännön asiantuntija eikä kielentutkija.

\section{Kieliopin kuvaus Aavikin ja Györffyn oppikirjoissa}

\subsection{Aavikin oppikirjan kielioppi}

Aavikin (mts. 2-10, 63) oppikirjan sisällössä kieliopilla on vankka asema: se on hyvin kielioppikeskeinen, lähes kieliopin ja oppikirjan välimuoto. Toisin kuin varhaisten suomen kielen kielioppien kieltä synkronisesti kuvaavat esitykset, jotka pyrkivät opettamaan tietyn kuvan suomen kielen kielijärjestelmästä, Aavik lähtee oppikirjansa kieliopin kuvauksessa liikkeelle kielten vertailusta (Vihonen 1978: 13, 16-17; Wiik 1991: 13-15; Voutilainen 2012: 57). Viron ja suomen kielen yhtäläisyyksiä ja eroja tarkastellaan läpi koko teoksen. Pystyäkseen ymmärtämään vertailut kirjan käyttäjän on edeltä käsin tunnettava suomen kielen verbintaivutus ja sijamuodot. Kirjoittaja aloittaa vertailemalla lähtö- ja kohdekielen nomineja ja verbejä keskenään: päivä, 'päew'; Jumala, 'jumal' tai he ovat siellä, 'nad on sään' (mts. 6-7). Aavikin käsitys on, että kielten yhtäläisyyksien oppiminen helpottaa kielen opiskelua; kieliopin eroja hän kutsuu sukulaiskielten omaleimaisuuksiksi (mts. III-V).

Aavikilla on tapana kertoa opittava kielioppiasia kappaleen alussa suomen- ja virokielisten esimerkkien avulla ja korostaa toisinaan 
kielioppipiirrettä tummennuksin, rajauksin tai kaavioin. Kielioppiasiaa seuraava tekstikappale tukee opetettavaa asiaa (esimerkki 1).

(1)

$\$ 7$. Mihin (minne) te menette? - Kuhu te lähete?

Me menemme metsään - Me läheme metsa.

[---]

Küsimise pääle kuhu? mille sisse? on ikka kahekordne hälik + $\mathbf{n}$ lõpuks (-aan, -ään, -iin j.n.e.) ['Vastauksissa kysymyksiin minne? mihin? on aina kaksoisäänne ja lopussa n’]

[---]

Mihin tämä juna lähtee? - Se tulee Viipurista ja lähte Helsinkiin. - Minne te aiotte? -

Minä aion Pietariin (Peterburisse). - Mistä (kust) te matkustitte (reisisite)

Tarttoon?

Minä matkustin rautateitse Tallinnasta Tarttoon ja sielt Riikaan, Riiasta höyrylaivalla Saksaan (Saksamaale), Saksast Englantiin (Englismaale), Englannista Ranskaan (Frantsusmaale) ja Italiaan (loe: idaliaan). - Ettekö halua' matkustaa’ Suomeen?

- Ikävä kyllä (kahju küll), en.

juna - rong höyrylaiva - aurulaew

aion - mull on plaaniks, mull on nõu, mõtlen.

$[---]$

(Aavik 1902: 9)

Yllä esimerkissä 1 kirjoittaja nostaa esille sisäpaikallissijoista illatiivin. Aavikin paikallissijojen esittämisjärjestys on kiinnostava. Palaankin hänen näkemykseensä kappaleessa 4.3.2. Hän pitänee illatiivin kertaamista tarpeellisena sen morfologisen rakenteen vuoksi. Kuitenkin esimerkkiin (1) liittyvä teksti edellyttää, että opiskelijalla on suomen kielen nominien sijataivutuksen aikaisempaa tuntemusta, koska kirjoittaja kertoo tässä yhteydessä ainoastaan illatiivin eri päätteet. mA-infinitiiviä (3. infinitiivi) käsitellään varhain, sivulla 14-15. Infinitiivirakenteet opetetaan nykyisissä S2-oppikirjoissa yleensä verbien aikamuotojen, modusten ja passiivin käsittelyn jälkeen (Karlsson 2009: 229-240).

Kirjoittaja etenee suomen kielen kieliopin kuvauksessaan kertauksenomaisesti kuin aikaisemmin opittuun palaten: omistusliitteistä 
puhutaan sivulla 16, verbin moduksista imperatiivin yksikkö ja monikko tulevat kirjassa jo sivulla 17 (vrt. Karlsson 2009: 141-145, 211-214). Nominien taivutustyypeistä -us, -is, -as, -nen -loppuisia sanatyyppejä esitellään kirjan alkupuolella (mts. 34, 36, 39). Kirjoittaja on koonnut kirjan loppuun (mts. 88-136) nominien sijamuodot taulukoksi (mts. 102-103), hän kuvaa vaativia nominien taivutustyyppejä (lapsi, kansi, onneton) (mts. 108-112), esittää kootusti verbien aikamuodot, modukset, passiivin, tärkeimmät VA- ja NUT-partisiippimuodot sekä suomen kielen neljä infinitiivimuotoa (mts. 120-125). Aavikin oppikirjan kielioppia käsitteleviin kappaleisiin ei toisinaan liity lainkaan tekstiosuutta (mts. 38-40), toisinaan kappaleessa on vain suomalaisia tekstejä (mts. 39-42). Kielioppi-käännösmenetelmä toteutuu kieliopin runsaana kuvauksena läpi teoksen, toisaalta käännöstekstejä on melko vähän mutta menetelmään kuulumaton suomen ja viron kielten vertailu on runsasta.

Aavikin oppikirjan kieliopin kuvaus muistuttaa monin paikoin Johannes Neuhausin (1919), Berliinin Friedrich Wilhelm -yliopiston suomalais-ugrilaisen osaston nykypohjoismaisten kielten lehtorin, suomen kielen oppikirjan Kleine Finnische Sprachlehre nebst einem Wörterverzeichnis der finnisch-indoeuropäischen Entlehnungen kuvausta. Myös Neuhausin kielioppiosuudet ovat pitkiä. Hänenkin kirjassaan (mts. 64-70) on kappaleita, joissa ei ole lainkaan tekstiosuutta, ainoastaan kieliopillisia selityksiä saksaksi suomalaisin esimerkein. Aavikin esityksestä poiketen Neuhaus ei kuitenkaan kuvauksissaan vertaile paljon saksan ja suomen kieltä keskenään. Mutta Neuhausinkin teoksen kuvaukset edellyttävät opiskelijalla olevan perusteelliset tiedot suomen kielen morfologiasta. Järventausta (2013: 97, 100) mainitsee myös artikkelissaan Neuhausin kirjan toisen kappaleen vaativan ja runsaan kielioppiosuuden, tekstikappaleiden ja kielioppiaineksen vähäisen yhteyden sekä niiden sisällöllisen mielivaltaisuuden. Nämä esimerkit vahvistavat käsitystä siitä, että S2-yliopisto-opetus 1900-luvun alkupuolella oli ennen kaikkea suomen kielioppipiirteiden hallinnan syventämistä siihen liittyvien tekstikappaleiden sisältöjen ja kieliopin esimerkkilauseiden avulla. Suomen kieli oli noihin aikoihin saavuttamassa yleiskielen muotonsa, eikä 
Aavikin ja Neuhausin tarkastelutapa vielä vastannut nykyistä suomi vieraana kielenä -kuvauksen näkökulmaa (Kieli ja sen kieliopit 1994: 31-37).

On helppo ymmärtää, että Aavik rakentaa oppikirjansa sisällön suomen ja viron kielen vertailulle. Vertailtavaa kielissämme on paljon, ja muillakin virolaisilla tiedemiehillä on ollut tapana käyttää vertailua kuvauksissaan (vrt. esim. Alvre 1969: 43-47). Kielten vertailu kielioppien kuvauksissa ei ollut muutenkaan harvinaista: sitä harrasti jo ensimmäisen suomenkielisen kieliopin kirjoittanut Henricus Corander (Koranteri) (1845: 6-7) kieliopissaan verratessaan suomen kielen ilmiöitä muun muassa kreikkaan ja ruotsiin. Aavikin oppikirjan ilmestymisen aikoihin oli käynnissä myös viron kielen uudistustyö, ja suomesta lainattiin satoja sanoja (R. Grünthal 2009: 231, 235-238). Viron kielen sanaston ja uusien kielioppirakenteiden kehittäjänä Aavik esittelee luonnollisesti oppikirjassaan sellaisia suomen kieliopillisia ratkaisuja ja sanastoa, joihin toivoo viron kielen uudistamisesta kiinnostuneiden opiskelijoiden tarttuvan.

\subsection{Kieliopin opetuksen kulku Györffyn kirjassa}

Kirjansa esipuheessa Györffy (mts. esipuhe) houkuttelee opiskelijoita opiskelemaan suomea kielisukulaisuuden, kielen mielenkiintoisuuden ja sukulaiskansan elämään tutustumisen vuoksi. Esipuheen sisällöstä saa sen vaikutelman, että kirjoittaja pyrkii houkuttelemaan pappisoppilaiden ohella myös muita suomen kielestä kiinnostuneita aloittamaan opinnot oppikirjansa avulla.

Györffyn (mts. 8-18) oppikirja noudattelee kieliopin esityksessään Aavikin tavasta poikkeavia sisällöllisiä ratkaisuja. Hänen kuvauksensa sisältö on tavanomaista S2-kielen opetuksen kuvausta, niin kutsuttua "helposta vaikeaan" -esitystapaa, jota jo von Becker (1824), Corander (Koranteri 1845) ja Eurén (1852) kieliopeissaan käyttävät. Sillä tarkoitetaan muun muassa, että näissä kieliopeissa verbioppi aloitetaan aktiivin indikatiivin preesensin yksikön ja monikon myönteisten muotojen esittelyllä, jota toisinaan seuraa verbien imperfekti-muodot ja vastaavat 
kielteiset muodot. Nominitaivutus aloitetaan nominien yksikön ja monikon nominatiivilla, yksikön genetiivillä ja paikallissijoilla.

Györffy aloittaa olla-verbin taivutuksella ja mainitsee suluissa suomen kielen ääntämisohjeenkin: minä olen (ejtsd [äännä:'] mine olën), 'én vagyok'. Verbintaivutuksen jälkeen kerrotaan nominatiivin yksikkö- ja monikkomuodot: talo 'ház'; talot 'házak'. Kirja opettaa aluksi muutaman yleisen verbin preesensin taivutuksen (sanoa, viedä, osata, lukea, oppia, tehdä; mts. 11-13). Nominien taivutusmuodoista ensimmäisenä opetetaan nominatiivi, genetiivi, akkusatiivi ja partitiivi, sitten alkaa astevaihtelun annostelu eri kappaleissa (kirkko, seppä, tyttö; mts.16), verbin imperfekti tulee sen jälkeen (mts. 25-26), sitten imperatiivi ja abessiivi, komparaatio, komitatiivi ja instruktiivi hieman myöhemmin (mts. 49, $56,60,64)$. Kieliopin kuvauksen järjestys muistuttaa paljon myös muita saman aikakauden suomi vieraana kielenä -oppikirjojen kuvauksia (vrt. Neuvonen 1935; Bergh 1940) ja jopa tämän päivän S2-oppikirjan esittämisjärjestystä (Pesonen \& Vehkanen 2016).

Györffyn (mts. 19-20) kirjassa kielioppiasia esimerkkeineen on kappaleen alussa, sitten seuraavat unkarinkielinen kieliopin selitys esimerkein, suomenkielinen lukukappale, unkarinkielinen keskustelukappale, kappaleeseen liittyvä suomi-unkari-sanasto ja vielä lopuksi unkarinkielinen "Huomautuksia"-kappale, jossa selitetään kappaleessa esitettyä kieliopin piirrettä unkariksi. Väitöskirjani aineiston aikuisille kirjoitetuissa oppikirjoissa lähtökielien ja muidenkin kielten välinen vertailu opetuksessa on tavallista (Vehkanen 2015: 227). Kuitenkin Györffyn (mts. 7-5) kirjassa suomen ja unkarin kieltä vertaillaan melko vähän. Uutta sitä vastoin on, että toisinaan kirjan kappaleissa esitetään opiskelijalle kysymyksiä, joihin opettaja odottaa oppilaan itse tuottamia vastauksia. Oppikirjan sisällön järjestys pysyy samana läpi kirjan. Sisällön punaisena lankana on kieliopin opetus, ja kappaleet sisältävät myös säännöllisesti käännöksiä unkarista suomeen ja päinvastoin. Se on kelpo esimerkki kielioppi-käännösmenetelmää noudattavasta oppikirjasta (ks. luku 5). Kirjoittaja hallitsee suomi vieraana kielenä -oppikirjan laadinnan näkökulman mallikkaasti. 


\subsection{Aavikin ja Györffyn astevaihtelun ja sijamuotojen kuvaus}

Tässä luvussa valotan kahden suomen kielen keskeisen morfologisen piirteen - astevaihtelun ja sijamuotojen - kuvauksia. Astevaihtelu esitetään suomen kieliopeissa usein "tärkeänä äännevaihteluna"; esim. Karlssonin (1983a: 36-46; 2009: 45-56) mukaan se on suomen taivutusmorfologian kuvatuin ilmiö. Karlsson (1983b: 322-337, 2009: 45-56) esittää kieliopissaan kaikkiaan 16 eri astevaihtelutyyppiä. Toisaalta ISK (2004: 70-81) pitää astevaihtelua melko tavallisena ilmiönä ja kertoo, että taajuussanastossa 1000 yleisimmästä sanasta noin kolmannes on astevaihtelutapauksia. Martin (1995: 101, 126, 267-270) on tutkinut ulkomaalaisten opiskelijoiden nominitaivutuksen oppimista introspektion avulla ja tullut siihen tulokseen, että opiskelijoiden eri tilanteissa tuottamista spontaaneista puheen ja kirjoitusten tuotoksista ykkösvartalon muodostusvirheet koskivat tavallisesti astevaihtelua sekä $e$ - ja $i$-vartaloisia ja $s$-loppuisia sanoja. Tutkija asettaa astevaihtelutyypit vaikeusasteiltaan kolmeen ryhmään: helpoimpana pidetään kvantitatiivista astevaihtelua sekä $t: d$ - ja $p: v$-vaihtelua, seuraavaksi tulee konsonanttiyhtymien vaihtelu. Vaikeimpina pidetään niitä astevaihtelutapauksia, joissa sanahahmo muuttuu huomattavan paljon taivutettaessa: esimerkiksi $k$ :n kvalitatiivista vaihtelua (joki: joen) sekä käänteistä astevaihtelua.

Väitöskirjani aineisto vahvistaa käsitystä astevaihtelun keskeisestä asemasta S2-kieliopin opetuksessa: sitä kuvataan aineiston kaikissa kielioppia sisältävissä aikuisten ja koululaisten oppikirjoissa. Siksi astevaihtelun opettaminen Aavikin ja Györffyn oppikirjoissa on hyvä ja tutkimisen arvoinen kohde tässä artikkelissa. Astevaihtelun kuvauksen laajuus väitöskirjani aineistossa vaihtelee: oppikirjojen kirjoittajat ottavat yleensä kirjan käyttäjät huomioon ja tarjoavat astevaihtelun kuvausta eri oppikirjojen lukijoille joko hyvin laajasti, keskimääräisesti tai vain vähän (Vehkanen 2015: 89). Laajalla astevaihtelun kuvauksella tarkoitetaan sellaista kuvausta, jossa on mainittu ISK:n esittämät variantit ja sen lisäksi vahvan ja heikon asteen poikkeuksia, käänteisen astevaihtelun eri muotoja sekä astevaihtelun ulkopuolelle jääviä sanatyyppejä, 
jopa historiallisia, murteellisia tai runokielen astevaihtelumuotoja (Neuhaus 1919: 14-15; Collinder 1941: 8-22). Keskimääräisellä kuvauksella tarkoitetaan tässä määrittelyssä astevaihteluvariantteja $k k: k ; k: ø ; n k: n g$;

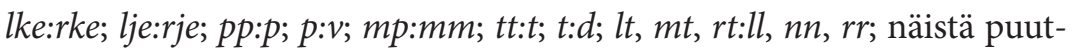
tuvat esimerkiksi ISK:n (2004: 73) variantit lp:lv; lk:l lj; rp:rv; rk:r rj; $h k: \sim h$ (Geijer \& Nieminen 1940: 30-31, 1942: 32-33; Bergh 1940: 35-38; Neuvonen 1935: 40-41). Vähäinen astevaihtelun kuvaus on tyypillistä fraasikirjojen kielioppiosuuksille. Siinä kuvauksen kohteena ovat lähinnä geminaattaklusiilit ( $k k: k, p p: p, t t: t)$ sekä muutama kirjoittajan valitsema varianttimuoto. Esimerkiksi Lehmann ja Torp (1951: 9) käsittelevät fraasikirjassaan klusiileja $k, p$ ja $t$ ainoastaan äänneopin yhteydessä eivätkä kuvaa ilmiötä lainkaan astevaihtelun näkökulmasta.

Toinen yhtä keskeinen suomen kielen morfologinen piirre S2-oppikirjoissa on sijamuodot ja niiden esittämisjärjestys. Aikuisille tarkoitettujen S2-oppikirjojen sijamuotojen esittämisjärjestyksen kuvausta voi väitöskirjani aineiston perusteella kutsua vaihtelevaksi. On selvää, että kun kirjoja kirjoitettiin kielitaidoiltaan ja taustoiltaan erilaisille opiskelijaryhmille eri puolilla maailmaa, eri kirjantekijät opettivat sijamuotoja kukin omassa järjestyksessään. Paikallissijojen esittämisjärjestys on varhaisissa oppikirjoissa suhteellisen epäyhtenäinen. Akkusatiivi ja kolme harvinaista sijamuotoa (abessiivi, komitatiivi, instruktiivi) sijoitetaan vaihtelevassa järjestyksessä muiden sijamuotojen joukkoon. Usein kirjojen keskivaiheilla esitetään nominien monikot, toisinaan myös lukusanat, pronominit ja adjektiivien komparaatiot. Verbien liittomuodot, tapaluokat, infinitiivi- ja partisiippimuodot esitetään taas kirjan viimeisimpinä asioina. Sille, mihin kohtaan kirjoittajat kielioppiaineksensa sijoittavat, ei näytä olevan loogista selitystä (Vehkanen 2015: 109, 115116). 


\subsubsection{Astevaihtelusta}

Ennakko-oletukseni mukaisesti Aavikin (mts. 98-102) vaativassa kieliopin kuvauksessa astevaihtelua kuvataan laajasti. Hänen tapansa on opettaa astevaihteluvariantit perusteellisesti, eikä hän ilmeisesti oleta runsaan kuvauksen tuottavan vaikeuksia filologisesti suuntautuneille S2-opiskelijoille. Kirjoittaja opettaa keskeisten muutosten lisäksi astevaihtelun ulkopuolelle jääviä poikkeustapauksia ja palauttaa esimerkkimuotoja jopa myöhäiskantasuomalaiseen asuun. Kuvaus on laajuudessaan Ison suomen kieliopin (2004) kuvauksen kaltaista. Aavik opettaa äännevaihtelun ryhmittelemällä eri variaatiot taulukkoon ja antaa niistä esimerkkejä (kk:k; pp:p; tt:t; k:ø; lke:lj; hke:hj; rke:rje; nk:ng; uku:uvu; yky:yvy; p:v; lp:l; rp:rv; t:d; ht:hd; lt:ll; mp:mm; nt:nn; rt:rr). Myös käänteinen astevaihtelu esitellään (mts. 23), esimerkkinä oppaan, opas. Kirjassa toisaalla (mts. 99-101) Aavik palaa illatiivin vahva-asteiseen muotoon ja palauttaa sen historialliseen illatiivimuotoon säte-hen (õigem säte ${ }^{\gamma}$ ). (L. Hakulinen 1979: 65-66) Kirjan käyttäjiltä vaadittiin perusteelliset tiedot suomen morfologiasta sekä suomen kielen historiasta. Yliopisto-oppikirjassa runsas kuvaus ei ole yllätyksellistä, vaan runsaiden variaatioiden esittelyä voidaan pitää odotuksenmukaisena.

Györffyn (mts. 16-17, 25, 34-35, 48-49, 55-57) ratkaisu on ehkä sekin odotuksenmukainen eli tyypillinen keskimääräisen laajuinen astevaihtelun kuvaus. Kirjoittaja opettaa suomen kielen äännevaihtelun annettuna, selittelemättä sitä mitenkään, eikä tuo esille asian keskeisyyttä suomen morfologiassa. Hänen astevaihtelun kuvauksen mallinsa poikkeaa Aavikin esityksestä. Hän ei opeta astevaihtelua taulukossa, vaan annostelee eri tapaukset kirjan kappaleissa ( $k k: k ; p p: p ; t t: t ; l k: l ; k: \varnothing ;$ $k: j ; p: v ; t: d ; h t: h d ; n k: n g ; m p: m m ; n t: n n ; l t: l l ; r t: r r ; k: v ; r k: r j ; l k: l j)$.

Kirjoittaja aloittaa kvantitatiivisen astevaihtelun kuvauksen (esimerkki 2) alaotsikon "Huomautuksia" yhteydessä (mts. 16) ja opettaa eri varianttien kuvaukset kirjan eri kappaleissa muiden kielioppi-ilmiöiden esittelyn lomassa. Hän jaottelee eri vaihtelutapaukset omiin ryhmiinsä 
(I-V) ja esittelee niitä harkintansa mukaisen määrän; käänteistä astevaihtelua ei opeteta.

(2) I csoport ['ryhmä]:

$\begin{array}{ll}\text { Erős fokon } & -k k,-p p,-t t \text { (vahva aste) } \\ \text { Gyenge fokon } & -k,-p,-t \text { (heikko aste) } \\ \text { Erős fok: } & \text { Gyenge fok: } \\ \text { kirkko } & \text { kirkon (templom) } \\ \text { seppä } & \text { sepän (kovács) } \\ \text { oppia } & \text { opin (tanulni) } \\ \text { tyttö } & \text { tytön (leány) } \\ \text { ottaa } & \text { otan (venni) }\end{array}$

(Györffy 1939:16)

Aavikin ja Györffyn oppikirjojen astevaihtelun kuvaukset ja opetus poikkeavat toisistaan ja kertovat osaltaan siitä moninaisesta S2-oppikirjatarjonnan kirjosta, jota ne tuolloin edustivat. Györffyn pappisopiskelijoille laaditussa oppikirjassa astevaihtelun kuvauksen määrä ja koko kieliopin sisältökin ratkaisuineen tuottavat opiskelijoiden käyttötarkoitukseen sopivan S2-oppikirjan. Aavikin suomen kielen opinnoissaan pitkälle ehtineet S2-opiskelijat taas saavat kirjoittajan ratkaisumallin ansiosta omaan tarkoitukseensa sopivan laajan astevaihtelukuvauksen.

\subsubsection{Sijamuodoista}

Aikojen saatossa suomen kielen 15 sijamuotoa on luokiteltu hyvin monella tavalla. Ainoastaan nominatiivi, Karlssonin (2009: 113) mukaan suomen kielen sijajärjestelmän "tukipilari", esiintyy kaikissa kirjoissa ensimmäisenä sijana. Sata vuotta sitten sijamuotoluettelo alkoi 12:ssa aikuisten oppikirjassa nominatiivilla, genetiivillä ja akkusatiivilla, ja kahdeksan kirjaa jakaa sijat kolmeen pääsijamuotoon (nominatiivi, genetiivi, akkusatiivi) ja 12 adverbiaalisijamuotoon (Vehkanen 2015: 108). Toiset kirjoittajat (Neuvonen 1935: 56; Tuomikoski \& Deans 1953: 56) jättävät akkusatiivin pois sijamuotoluettelostaan, ja muutama kirjoittaja antaa akkusatiiveille järjestysluvut I ja II (Bianchini 1942: 2, 8; Englund 1942: 
115-123; Englund \& Wolf 1953: 127-136). Luultavasti järjestykseen ovat vaikuttaneet samaan aikaan ilmestyneiden S2-oppikirjojen sisällölliset ratkaisumallit, ehkä lähtökielen nominien taivutusjärjestelmä sekä kirjoittajien omat näkemykset sijojen hyvistä ja opiskelijoille hyödyllisistä esittämisjärjestyksistä. Nykyisissäkin kieliopeissa sijojen määrä ja niiden opettamisen oikea hetki vaihtelevat eri oppikirjoissa. Karlsson (2009: $145-150,307)$ ei erota kieliopissaan erillistä akkusatiivisijaa. Bessonoff ja Hämäläinen (2011: 19-23, 29-32) opettavat ensimmäisinä sijoina paikallissijoista inessiivin ja adessiivin, sitten opetetaan genetiivi, jonka yhteydessä kirjoittajat kertovat myös sanan vartalosta. Suomen kielen sanavartalot he opettavat liittämättä niiden muodostamista mihinkään tiettyyn sijamuotoon (mts. 45), partitiivin Bessonoff ja Hämäläinen opettavat paikallissijojen ja genetiivin jälkeen (mts. 66-67). Myös Neuhaus ja Aavik järjestävät paikallissijat omalla, persoonallisella tavallaan.

Aavik (mts. 102) aloittaa sijamuototaulukkonsa nominatiivilla, genetiivillä ja akkusatiivilla ja opettaa sen jälkeen niin kutsutut yleiset paikallissijat: translatiivin, essiivin ja partitiivin. Sisä- ja ulkopaikallissijojen järjestys on nykylukijasta omintakeinen, sillä Aavik haluaakin aloittaa ulkopaikallissijoilla ja kertoo ne omassa esittämisjärjestyksessään: allatiivi, adessiivi ja ablatiivi. Sitten tulevat sisäpaikallissijat: ensimmäisenä illatiivi ja sen jälkeen inessiivi ja elatiivi. Lopuksi kirjoittaja luettelee harvinaiset sijamuodot: abessiivin, komitatiivin ja instruktiivin. Samanlaista omintakeista linjaa edustaa Neuhausinkin (1919: 24-30) esittämisjärjestys: ensinnä illatiivi, sitten inessiivi ja tämän jälkeen yllättäen allatiivi, ablatiivi, sitten elatiivi sekä adessiivi. Myös loput sijamuodot Neuhaus asettelee omaan järjestykseensä: harvinaisten sijamuotojen abessiivin, komitatiivin, instruktiivin jälkeen tulevat translatiivi, essiivi ja harvinainen prolatiivi. Kumpikaan kirjoittajista ei anna selitystä sijamuotojen esittämisjärjestykselle.

Györffy (mts. 67) aloittaa sijamuotojen opettamisen kirjassaan seuraavasti: nominatiivi, genetiivi, akkusatiivi, partitiivi, translatiivi, essiivi. Tämän jälkeen hän esittelee nykyisin melko tavallisessa järjestyksessä sisä- ja ulkopaikallissijat: inessiivi, elatiivi, illatiivi, adessiivi, ablatiivi, 
allatiivi. Györffyn luettelon lopussa ovat abessiivi, komitatiivi, instruktiivi sekä myös Neuhausin mainitsema prolatiivi. Sijamuotojen järjestys poikkeaa Györffyn maanmiehen Szinnyein järjestyksestä sikäli, että hän opettaa Szinnyein opetuksesta poiketen vasta sisä- ja ulkopaikallissijojen jälkeen abessiivin, komitatiivin, instruktiivin sekä prolatiivin. Unkarissa 1990-luvulla kirjoitettu S2-oppikirja (Karanko ym. 1990: 290) käyttää Györffyn sijamuotojärjestystä, mutta kirjoittajat jättävät Szinnyein tapaan prolatiivin mainitsematta.

Aavikin paikallissijojen opettamisjärjestyksestä on Györffyn kirjan mallissa siirrytty jo niin kutsuttuun tavanomaiseen paikallissijojen ratkaisumalliin. Emme voi tietää, mikä Aavikin esittämän järjestyksen ajatuksena kielenopetuksellisesti on ollut. Toisaalta esimerkiksi Bessonoffin ja Hämäläisen (2011) tuoreessa oppikirjassa paikallissijoista inessiivi ja adessiivi opetetaan heti sijamuotojen opetuksen alussa, varmaankin yleisyytensä tähden.

Olen väitöskirjassani todennut, että lähes 100 vuotta sitten ilmestyneiden S2-oppikirjojen sijamuotojen eri esittämisjärjestyksiä voi parhaiten kuvata ilmauksella "sisältöjen moninaisuus". Kuten yllä olen esittänyt, varhaisissa Aavikin (1902) ja Neuhausin (1919) oppikirjoissa paikallissijat esitellään omalla, poikkeavalla tavallaan. Myöhemmin ilmestyneissä oppikirjoissa, kuten Györffyn, ne esitetään nykyisessä, melko yleisesti käytetyssä järjestyksessä: inessiivi, elatiivi, illatiivi; adessiivi, ablatiivi, allatiivi (Vehkanen 2015: 117).

\subsection{Yhteenveto}

Suomi vieraana kielenä -oppikirjoissa kielioppia opetettiin lähes 100 vuotta sitten todella monella tavalla: tekstien lomassa, kirjan lopussa, alussa tai kirjaan liittyvässä erillisessä kieliopissa. Kielioppiasia voi olla erillisenä kokonaisuutena, johon tekstikappaleissa viitataan tai ei viitata. Opiskelijalle saatettiin tarjota samassa oppikirjassa koko suomen kielen muoto-oppi ja usein lyhyesti myös lauseoppi (Vehkanen 2015: 115-116). Kirjoittajat tekivät oppikirjojaan kaukana toisistaan eri 
opetustarkoituksiin. Se, mihin tarkoitukseen kirja tehtiin, määräsi kieliopin opetuksen sisällön. Oppikirjoja kirjoittivat alan asiantuntijat, joilla oli oma näkemyksensä kielemme opettamisen parhaasta tavasta ja kielioppiaineksen esittämisen tärkeysjärjestyksestä juuri hänen opiskelijaryhmälleen.

Aikuisille tarkoitettu kieliopin kuvaus muuttuu ajan mittaan: 1900luvun alun oppikirjat edustavat yliopisto-opetukseen kirjoitettuja runsaasti kielioppia sisältäviä teoksia, mutta 1920-luvulla alkaa kansainvälisen kanssakäymisen lisääntyessä ilmestyä fraasikirjoja, jotka edustavat uutta, puheen opetusta korostavaa kielenopetuksellista suuntausta. Näissä kirjoissa kieliopin opetus jää taka-alalle, ja opetuksen keskiöön tulee puheen opetus lähtö- ja kohdekielen fraasien avulla (Vehkanen 2105: 46, 54). Fraasikirjojen ohella ilmestyy kuitenkin runsaasti myös niin kutsuttuja tavanomaisia S2-oppikirjoja, joissa suomen kieliopin keskeiset piirteet opetetaan Györffyn oppikirjan opetussisällön tavoin (Neuvonen 1935; Bergh 1940; Englund 1942). Jos vertaa 1900-luvun lopulla ja 2000-luvun alussa pitkään käytössä olleiden suomi toisena ja vieraana kielenä -oppikirjojen sisällöllisiä rakenteita (Aaltio 1992; Nuutinen 1996; Lepäsmaa \& Silfverberg 1998) näihin vanhempiin aikuisoppikirjoihin, huomaa, että näissä uudemmissakin oppikirjoissa kielioppi muodostaa kirjojen sisällön punaisen langan. Samoin 2000luvun koululaisten S2-oppikirjoissa sisältö on rakentunut kieliopin kuvauksen varaan, vaikka kielioppiaines onkin siirretty tarkoituksellisesti tekstikappaleen loppuun (Kuukka ym. 2011; Leiponen 2000).

Luvuissa 4.3, 4.3.1 ja 4.3.2 kerron tutkittavien oppikirjojen kuvaustapojen ominaispiirteistä. Näyttää siltä, että yhteistä Aavikin ja Györffyn kieliopin kuvauksille on niiden runsaus sekä se, että kirjat on kirjoitettu homogeenisille - viron- ja unkarinkielisille - opiskelijaryhmille, joille kohdekielen piirteet voidaan selittää lähtökielen avulla. Samoin yhteistä on myös uuden kappaleen kielioppipiirteen kuvaus ja määritelmä: ilmiö kuvataan hyvin usein molempien oppikirjojen kappaleiden alussa sääntöjä ja esimerkkejä piirteestä antaen. Mutta kirjoittajien kuvauksissa on myös eroavaisuuksia, jotka säätelevät kirjojen kieliopin kuvauksen 
ratkaisuja ja jotka johtuvat kirjojen eri käyttötarkoituksista. Aavik vertailee läpi teoksensa suomea ja viroa hyvin suomen kieliopin hallitseville oppikirjansa käyttäjille ja nostaa mielestään tärkeitä kielioppiasioita esiin kappaleissaan oman ratkaisunsa mukaan. Aavik kuvaa toisinaan keskeiseksi katsomaansa kielioppipiirrettä koko kappaleen verran (mts. 23-24), tai toisaalla hän tarjoaa lukijoilleen kokonaisen kappaleen fiktiivisiä tekstejä (mts. 40-42). Györffyllä oli erityistehtävänä tuottaa unkarinkielisille, luterilaisille pappisoppilaille oppikirja. Hän on päättänyt opettaa heille suomen kielioppia saman formaatin mukaan läpi koko kirjan. Kirjoittaja vertailee suomen ja unkarin kielen kieliopillisia yhtäläisyyksiä ja eroja vain vähän; sitä vastoin hän ottaa kirjassaan käyttöön uutena pedagogisena ratkaisumallina kysymykset, joihin kirjaa käyttävä opettaja odottaa oppilaan itse tuottamia vastauksia. Tässä Györffyn oppikirjan sisältö lähestyy jo kommunikatiivista opetusmenetelmää (ks. luku 3.3.1.).

Yllä mainitut viron ja unkarin S2-kieliopin opetuskulttuurin esimerkit kertovat niiden erilaisista ratkaisumalleista. Ne täyttävät omanlaisine kuvauksineen epäilemättä kirjojen kohderyhmien tarpeet. Aavikin oppikirjan sisältö sopii erinomaisesti virolaisten, hyvin jo suomen kieltä hallitsevien opiskelijoiden käyttöön, kun taas Györffyn teos on sisällöllisiltä ratkaisuiltaan sopiva ja käyttökelpoinen unkarilaisten pappisopiskelijoiden suomen kielen opetukseen. Se, että Aavik esimerkissä (1) oppikirjansa alussa opettaa sijamuodoista illatiivin, kertonee hänen pitävän illatiivia erityisen tärkeänä sijojen joukossa. Tänä päivänä illatiivi opetetaan yleensä sisäpaikallissijoista viimeisenä, koska sen morfologia on mutkikkainta eli päätteitä on useita $(-V n /-h V n /$-seen; Pesonen \& Vehkanen 2016: 36, 46). Kirjan esimerkin yhteyteen liittyvä tekstin sisältö olettaa kirjan käyttäjän hallitsevan suomen kielen muut paikallissijat, joiden muodostuksen opettamista kirjoittaja ei katso siinä yhteydessä tarpeelliseksi esittää. Tämä yhden sijamuodon opetuksen korostaminen antaisi ymmärtää, että Aavikin kirja olisi ikään kuin kertauskirja, jossa kirjoittaja nostaa esiin virolaiselle opiskelijalle vaikeasti hallittavia suomen kielen morfologian piirteitä. 
Györffyn kirjasta unkarinkieliset, luterilaiset pappisopiskelijat oppivat tarpeellisen määrän tietoa suomen kielen keskeisistä piirteistä. On merkityksellistä, että opettaja pyrkii antamaan oppilailleen nimenomaan heidän tarvitsemaansa tietoa: mitä oppija tarvitsee opiskeltavasta kielestä heti opetuksen alussa, ja mitkä asiat voi opettaa myöhemmin. Sama pätee kieliopinkin opetuksessa; siinäkin oppikirjan kirjoittaja tarjoaa kielioppia annostellen sitä sopiviksi kokonaisuuksiksi, ja kieliopin kuvaus etenee opettajan oman käsityksen mukaisessa vaikeutumisjärjestyksessä. (Nuutinen 1996: 14-18)

Toteutumatta ovat saattaneet jäädä ne molempien oppikirjojen kirjoittajien esittämät toiveet, että kirjoja käyttäisivät suomen kielen opiskelussaan varsinaisten käyttäjäkohderyhmien lisäksi muutkin suomen kielestä kiinnostuneet virolaiset ja unkarilaiset opiskelijat. Se lienee vaikeata Aavikin kirjan vaativan kieliopillisen sisällön takia. Györffyn kirjan luterilaiset, uskonnollissävytteiset tekstit taas saattoivat karkottaa muut kuin teologian opiskelijat tämän kirjan ääreltä ja vähentää kiinnostusta suomen kielen opiskelua kohtaan.

\section{Opetusmenetelmistä}

\subsection{Taustaa}

Vaikka niin sanotun modernin kielenopetuksen katsotaan syntyneen 1800-luvun loppupuolella koulutusjärjestelmässä ja kielenopetuksen menetelmissä tapahtuneiden muutosten seurauksena, klassisen latinan opiskelu, sen kieliopin ja retoriikan analysointi säilyttivät kuitenkin edelleen asemansa vieraan kielen opetuksen mallina 1600-luvulta aina 1800-luvulle asti. (Laihiala-Kankainen 1993: 217, 230-231, 255; Jaakkola 1997: 54) Niin Euroopassa kuin Suomessakin vieraan kielen opetus perustui vuosina 1840-1940 kielioppi-käännösmenetelmään, jonka pääpaino oli lukemisessa ja kirjoittamisessa. Lause oli kielenopetuksen ja harjoittelun kohde. Lauseiden kääntäminen oli opetusmetodin keskiössä. Puhumiseen tai kuuntelemiseen ei kiinnitetty huomiota. Opittavan kielen kieliopin hallitseminen oli oppimistavoite: joka hallitsee kieliopin, 
hallitsee myös opittavan kielen. Metodi on edelleen jossain muodossa käytössä eri puolilla maailmaa varsinkin silloin, kun opiskelun päätarkoitus on kirjoitetun tekstin ymmärtäminen (Elomaa 2009: 61).

Suomessa syntyi myös kieliopin opetusta vastustava didaktinen suuntaus 1900-luvun taitteessa, niin kutsuttu herbartilaisuus. Reformiliike taas syntyi vastareaktiona kielioppi-käännösmenetelmälle 1880-luvun lopulla. Yhteistä näille molemmille suuntauksille, herbartilaisuudelle ja reformiliikkeelle, oli juuri kielioppikielteisyys (Koskinen 1988: 70, 90; Syväoja 2004: 50-52). Reformiliikkeen pääedustajat englantilainen Henry Sweet, saksalainen Wilhelm Viëtor ja ranskalainen Paul Passy korostivat puhutun kielen tärkeyttä vieraan kielen oppimisessa ja olivat vakuuttuneita siitä, että kieltä voitiin oppia ainoastaan kuuntelemalla ja jäljittelemällä ilman kieliopin opintoja. Tämä johti siihen, että seuraavaksi syntyi 1880-luvulla niin kutsuttu suora menetelmä, jonka tavoitteena oli aktiivinen kielen opiskelu puheen opetuksen ollessa opetuksen keskiössä. (Richards \& Rodgers 2001: 5-7, 55; Elomaa 2009: 61-62; Jaakkola 1997: 54-55)

Ensimmäisen maailmansodan jälkeen kanssakäyminen eurooppalaisten valtioiden välillä lisääntyi. Tarvittiin kuullun ymmärtämistä korostavaa oppimateriaalia. Tästä saivat alkunsa yksityisopiskeluun soveltuvat keskustelu- ja fraasioppikirjat. (Richards \& Rodgers 2001: 7-14) Maailmansotien välisenä aikana sekä Yhdysvalloissa että Euroopassa oli käytössä tilannepohjainen kielenopetusmenetelmä. Menetelmässä oli olemassa tietty yhteisymmärrys siitä, kuinka paljon kielioppia, lauseoppia ja sanastoa alkeiskurssilla, keskitason ja edistyneiden vieraan kielen opetuskurssilla tulee opettaa. Suomen kouluopetukseen tämä induktiiviseksi puheopetukseksi nimitetty opetustyyli tuli 1940-luvulla. Menetelmää seurasi Yhdysvalloissa sotilastulkkien tarpeeseen kehitetty strukturaalis-lingvistinen/behavioristinen oppimiskäsitys eli audiolingvaalinen menetelmä. Seuraava jatkokehitelmä oli audiovisuaalinen menetelmä, joka opetusmenetelmänä taas nojaa kuuntelemisen lisäksi myös näkemiseen. Se levisi Yhdysvalloissa 1950-luvulla ja korosti tilanteen tutuksi tekemistä oppilaalle ensin visuaalisin keinoin. Vasta 
visualisoinnin jälkeen seuraa kielellinen osuus: ulkoa opittavia dialogeja, kielistudiossa tehtäviä drilliharjoituksia, joihin kuuluivat stimulus, oppilaan vastaus, oikea vastaus (vahvistus) ja sen toisto. Kommunikatiivinen kielenopetus eli niin kutsuttu kommunikativinen lähestymistapa valtasi alaa kielenopetuksessa 1960-luvun lopulta lähtien. Kieli nähtiin merkityksen ymmärtämisen ja ilmaisun välineenä ja sen funktionaalista ja kommunikatiivista merkitystä alettiin korostaa (Jaakkola 1997: 55; Elomaa 2009: 62-64; Richards \& Rodgers 2001: 11, 38-39, 50-67).

\subsection{Aavikin ja Györffyn oppikirjojen opetusmenetelmistä}

Sajavaaran (1999: 106-115) mukaan kontrastiivinen tarkastelu, eri kielten keskinäisten samankaltaisuuksien tai erilaisuuksien havaitseminen auttaa ennakoimaan vieraan kielen opetuksen mahdollisia vaikeuksia. Väitöskirjassani tutkituista aikuisten S2-oppikirjoista kielten välistä vertailua on lähes kaikissa. Tavallisesti kirjan kirjoittaja vertailee kirjansa lähtökieltä ja opittavaa kohdekieltä toisiinsa. Tukholman korkeakoulun suomen kielen ja kirjallisuuden lehtori Volmar Bergh (1940: 5-11) esimerkiksi vertailee oppikirjassaan ruotsin ja suomen verbejä sekä vokaaleja ja huomauttaa, ettei suomen kielessä ole vahvoja verbejä ja että kirjoittajan mielestä suomen kielen vokaalit ovat "tummemman värisiä" kuin ruotsin vokaalit. Bergh myös esittelee kirjansa alussa viikinkiajan skandinaaviset lainasanat, jotka nykyään ovat yhteisiä suomelle ja ruotsille, sekä vertaa toisiinsa suomen ja ruotsin ääntämistä. Pariisin Itäisten kielten ja kulttuurien korkeakoulussa (Institut National des Langues et Civilisations Orientales, INALCO) opettanut Eero Neuvonen (1935: 43) vertaa yliopisto-opiskelijoille laatimassaan alkeisoppikirjassa suomen ja ranskan menneen ajan verbinmuotoja ja toteaa niissä olevan samankaltaisuutta. Helsingin sosiaalialan oppilaitoksen lehtori Aune Tuomikoski sekä maisteri Helen Deans (1952: 45) vertailevat Neuvosen kirjan vastaavassa englanninkielisessä alkeiskurssissaan suomen kielen preesensin eri käyttömuotoja päättymättömässä tekemisessä englannin gerundimuotoon. Vaikka Neuvosen ja Tuomikosken ja Deansin kirjojen 
tekstiosuudet ovat toistensa kopioita, kielioppiosuuksissa esitetään eri argumentteja eri apukielien perusteella.

Aavikin ja Györffyn oppikirjojen sisältöjen opetustavoissa on yhteistä kieliopin keskeisyyden lisäksi se, että molemmat oppikirjat on laadittu yhden lähtökielen käyttäjille. Viroa ja unkaria käytetään selityksissä läpi koko kirjan (ks. esimerkit 1,2). Edelleen lähtö- ja kohdekielen vertailua on molemmissa oppikirjoissa, tosin Györffyllä vähän ja Aavikilla paljon.

Györffy vertailee kirjansa alussa suomea ja unkaria kappaleessa, jonka otsikko on "A finn nyelv sajátosságai" ('suomen kielen ominaispiirteet’; esimerkki 3).

(3) A főhangsúly - mint a magyarban - mindig a szó első szótagján van. ['Sanan pääpaino - kuten unkarin kielessäkin - on aina ensimmäisellä tavulla.']

(Györffy 1939: 5-7)

Györffyllä (mts. 77-79) oli vielä kappaleen alun kielioppiesimerkkilauseiden ja kieliopillisten selitysten ja lukukappaleen jälkeen kappale nimeltä Megjegyzések ('Huomautukset'), jossa kirjoittaja usein selittää unkariksi kappaleessa käsiteltyä asiaa ja toisinaan vertaa sitä suomen kieleen tai esimerkiksi saksan vastaavaan ilmiöön.

Kuten olen edellä jo maininnut, Aavikin oppikirjassa kielioppia opetetaan vertaamalla viron ja suomen kielen yhtäläisyyksiä ja eroja läpi koko kirjan. Vertailu on kirjan kieliopin kuvaamisen keskeinen menetelmä. Esimerkissä (4) Aavik selittää kappaleen sanojen merkityksiä vertailemalla suomen sanoja niiden etymologisiin vastineisiin virossa.

(4) [---] puhun (Eesti puhun) - räägin (wõrdl. „juttu puhuma”) [ts. viron puhuma merkitsee 'puhaltaa', mutta idiomissa juttu puhuma sen voi ymmärtää myös 'puhumiseksi']

katson (Eesti katsun ['koetan']) - waatan (kui asja katsutakse, siis waadatakse, teda kõige päält). ['kun esinettä kosketetaan (katsutakse), silloin sitä ensiksi tarkastellaan, katsellaan (vaadatakse)']

(Aavik 1902:10) 
Suomen kielen ja opiskelijan äidinkielen vertailua esiintyy väitöskirjani aineiston varhaisissa aikuisille kirjoitetuissa S2-oppikirjoissa suhteellisen paljon, mikä kertoo siitä, että kirjoittajat pitävät kielten vertailua opiskelua edistävänä seikkana. Uudemmatkin suomen kielen oppikirjat esittelevät suomen kielelle ominaisia piirteitä vertaamalla niitä muihin kieliin, englannin ohella esimerkiksi saksaan ja ranskaan. Tällaisina piirteinä S2-oppikirjoissa ja kieliopeissa mainitaan esimerkiksi suomen kielestä puuttuvat kieliopilliset suvut, artikkelittomuus sekä sijapäätteet ja omistusliite (Karlsson 1983a: 16-17; White 1993: 11-12).

Györffyn kirjassa uusi pedagoginen menetelmä on opiskelijoille tehtävät kysymykset. Jo varhaisessa Kallion (1904: 4) äidinkieleltään ruotsinkielisille koululaisille kirjoittaman S2-oppikirjan toisen osan tekstiosuuden alussa on erillinen aloitussivu, jossa otsikkona on "Harjoituskappaleita. Öfningsstycken”. Sitä seuraavat oppikirjan tekstikappaleet. Mistään nykymuotoisesta harjoitusosiosta ei kuitenkaan ollut kysymys, vaan tässä kaikkea kieliopin opetuksen ohessa olevaa tekstimateriaalia kutsutaan harjoituksiksi. Myös Neuhaus (1919: 58) käyttää oppikirjassaan termiä Übung, mutta se tarkoittaa tässä yhteydessä muutamaa arkipäivän sanontaa, jolle kirjoittaja antaa saksankieliset vastineet (esimerkki 5). Emme tiedä, onko niitä mahdollisesti käytetty oppitunnilla puheharjoituksina (Neuhaus 1919: 48-49).

(5) Beispiele.

Hyvää päivää herra! Guten Tag, mein Herr!

Hyvä herra! Mein Herr!

Herraseni! Mein Herr!

Hyvät herrat! Meine Herren!

Nimeni on Mein Name ist.

Minun nimessäni In meinem Namen.

Mikä on nimenne? Wie ist Ihr Name? oder Miksikä Teitä nimitetään? Onko neiti tyttärenne täällä? Ist Ihre Fräulein Tochter hier?

[---] 


\section{Übung 3.}

itse kuningas der König selber.

ajatella itsekseen bei sich (selbst) denken.

mennä itseensä in sich gehen.

(Neuhaus 1919: 48-49)

Nykymuotoiset harjoitukset ilmestyivät S2-oppikirjoihin 1930-luvulla. Erityisesti neuvostoliittolaiset kirjoittajat käyttivät niitä runsaasti kirjoissaan (Riihonen 1929; Salo 1932; Laatikainen 1940), mutta Robert Englundin (1946) ja yhdysvaltalaisen Thomas A. Sebeokin (1947) ohella myös Györffyllä oli niitä runsaasti. Kun Aavikin kirjan opetusmenetelmällinen ratkaisumalli on viron ja suomen kielen vertailu, esittää Györffy taas oppikirjassaan kysymykset, joihin kirjaa käyttävä opettaja odottaa opiskelijan itse tuottamia vastauksia (esimerkki 6).

(6) Feladat. (Tehtävä.)

Feleljünk a következő kérdésekre magunk szerkesztette mondatokban. ['Vastatkaamme seuraaviin kysymyksiin itse tuotetuilla lauseilla.']

Kysymyksiä:

Kutka matkustivat kerran yhdessä?

Kuinka he matkustivat?

Kuka puhui ensin?

Mitä kissa sanoi?

Miksi kissa pelkäsi? [---]

(Györffy 1939: 29)

Györffyn esimerkissä (6) näkyy piirteitä 1960-luvun kommunikatiivisesta opetusmenetelmästä, jossa kysymykset ja niihin vastaaminen, pyyntöjen tekeminen ja niihin reagoiminen sekä kaikki, mikä viittaa kielen funktioon ja puheen pragmaattisiin malleihin, ovat opetuksessa läsnä (Elomaa 2009: 63-64, 67-68). Esimerkin 6 kysymyksissä on aineksia induktiivisen opetuksen perusteista. Siinä opiskelija päätyy yleisiin sääntöihin esimerkkien avulla. Vastakohtanahan on deduktiivinen opetus, jossa edetään säännöistä kielen käytön harjoitteluun. Sokrateen kyselevä menetelmä loi pohjan induktiiviselle opetukselle, joka tähtää oman ajattelun ja kokemuksen analysointiin (Jaakkola 1997: 59; Laihiala-Kankainen 1993: 62). 
Harjoituksen käyttö kirjan tekstiosuuden nimessä on askel kohti nykyistä vieraan kielen oppikirjan harjoitusosiota. Englundin oppikirja muistuttaa menetelmiltään jo (esimerkki7) nykyistä S2-kielenopetusta: harjoituksissa harjoitetaan jo muutamia kielen eri osa-alueita.

\section{(7) Övningar.}

Svara på frågorna. Missä olette? Mistä tulette? Minne menette? med följande ord: suomalainen sauna finsk bastu, linja-autoasema linjebilstation (yttre lokalkasus, satama hamn (inre lokalk.), [---]

(Englund 1946: 19)

Aavik ei käytä oppikirjassaan harjoitus-nimitystä, mutta kyllä hänkin varmasti toivoi, että opettaja sai tunnilla Aavikin kirjaansa laatimiin kysymyksiin suullisia, itsetuotettuja vastauksia (esimerkki 7).

(7) Ota' jalkasi (oma jalg? oma jalad?) pois! Kumpi on kauniimpi, sinun hattusi vai minun hattuni? Paljonko olette maksaneet koirastanne (oma koera eest)? [---]

(Aavik 1902: 17)

Edellä lueteltujen opetusmenetelmien lisäksi voi vielä mainita, että sekä Aavik että Györffy opettavat opiskelijoita keskustelemaan tarjoamalla kirjoissaan aitoa keskustelua jäljitteleviä dialogitekstejä. Györffyn dialogi esimerkissä 8 on miellyttävää, rentoa keskustelua ja oppilasta keskustelemaan houkuttelevaa.

(8) Olvasmány. (Lukukappale.)

Asemalla.

„Hyvää huomenta”, sanoi ylioppilas Seppä eräälle ystävällensä, jonka hän tapasi Helsingin aseman odotussalissa.

„Huomenta”, vastasi hän.

"Mihin, mihin?”

„Matkustan Turkuun.”

„No, miksi?”

„Kirjoittaudun Turun yliopistoon.”

„Kuinka kauan opiskelet siellä yliopistossa?”

„Mahdollisesti kaksi lukukautta. Matkustatko sinäkin?”

„En. Odotan vieraita.” [---]

(Györffy 1939: 85) 
Györffyn dialogissa (esimerkki 8) keskustelevat ylioppilas Seppä sekä nimeltä mainitsematon salaperäinen eräs ystävä. Dialogihan on muodollisesti ja konventionaalisesti korrekti malli opiskelijoille mahdollista keskusteluharjoitusta varten.

Aavikin esimerkissä (9) dialogi edustaa 1900-luvun alun kohteliasta keskustelua teitittelymuotoineen. Se eroaa nykypäivän oppikirjatekstien vuoropuheluista ja kuulostaa nykylukijasta hiukan teennäiseltä, mutta on ajankohtaansa hyvinkin sopivaa vuoropuhelua. Dialogia ei ole otsikoitu, ja sen keskustelijat ovat vailla nimiä.

(9) Eikö teillä ole' halua tulla' kävelemään? Ilma on ihana ja aurinko paistaa niin lämpimästi.

Sentähden on hyvin hauskaa kävellä. - Ei minulla ole’ tällä hetkellä (sel) aikaa.

- Mikä asia estää teitä tulemasta. - Rupesin (hakkasin) lukemaan erästä hauskaa kirjaa.

Mutta minä pyydän teitä tänä iltana teatteriin. Tahdotteko tulla? En tiedä (tea) vielä. [---]

(Aavik 1902: 15)

Vaikka yllä (esimerkit 8, 9) Györffyn ja Aavikin keskustelua jäljittelevät dialogit antavat opiskelijalle esimerkkejä keskusteluharjoituksiin, niistä puuttuvat kuitenkin vuorovaikutuksellisen puhetilanteen elekieli, tauot ja henkilöiden ilmeet. Näiden oppikirjojen tekstit ovat sekä ei-suomalaisille kirjoitettuja että ei-suomalaisten kirjoittamia. Vaikka kysymyksessä on kaksi sukukielen S2-oppikirjaa, poikkeavat molemmat lähtökielet kuitenkin opittavasta suomen kielestä sen verran, että oppikirjojen opetusmenetelmien sisällöllinen toteutus on näissä esimerkeissä laadittu suomen kielen rakenteita korostamaan (Suni 2008: 36). Kirjoittajien eisuomalainen kulttuuritausta sekä kirjan ilmestymisajankohta heijastuvat oppikirjojen tekstien sisältöihin, minkä suomalainen lukija aistii jonkinasteisena vierautena. Kirjojen ilmestymisen välillä on yli 30 vuotta. Kirjoittajien oma ajatusmaailma ja kirjojen ilmestymisen ajallinen ero ovat aistittavissa dialogien sisällöistä.

Olen tässä kappaleessa kuvannut, mitä opetusmenetelmiä Aavik ja Györffy ovat oppikirjoissaan käyttäneet. Opetusmenetelmien muutokset 
tapahtuvat 1900-luvulla osittain saman aikaisesti Euroopassa, Yhdysvalloissa ja Suomessa. Kielioppi-käännösmenetelmä säilyy tutkituissa kirjoissa menetelmänä, Aavik vertailee runsaasti lähtökielen ja kohdekielen kielellisiä eroja ja yhtäläisyyksiä opetuksensa tukena. Györffy tuo oppikirjaansa jo itsenäistä ajattelua vaativia nykymuotoisia harjoituksia, ja keskustelemaan rohkaistaan kirjojen dialogit esimerkkeinä.

\section{Yhteenveto}

Olen tarkastellut tässä artikkelissani kahden vanhan S2-oppikirjan tapaa opettaa suomea vieraana kielenä. Tutkittuani kirjoittajien lähtökohtia oppikirjojen kirjoittamisessa olen tullut siihen lopputulokseen, että molemmilla kirjoittajilla on ollut hyvät lähtökohdat oppikirjojensa laatimiseen. Johannes Aavikilla oli ollut kiinteät suhteet Suomeen jo opiskeluajoistaan lähtien, hänen viron kielen uudistustyönsä perustui nimenomaan ikään kuin suomen kielen ja viron kielen "yhteistyöhön". Siihen tarpeeseen kirjoittajan kirjoittama oppikirja hyvin sopikin myös sisällöllisesti. Kirjan kohderyhmä olisi parhaimmillaan juuri tuo viron kielen uudistustyöstä ja suomen kielen opiskelusta kiinnostunut opiskelijajoukko, jolla oli vankat tiedot suomen kielestä jo entuudestaan. Myös Béla Györffyn lähtökohta oppikirjansa kirjoittamiseen oli erinomainen sekä hänen papillisen taustansa että suomi vieraana kielenä -opetustaitonsa ansiosta. Hän oli ryhtynyt tähän erityistehtävään lujittaakseen Suomen ja Unkarin luterilaisten kirkkojen välistä yhteistyötä, ja siihen kuului erottamattomasti myös pappisoppilaiden suomen kielen opiskelu - Györffyn oppikirjan avulla.

Miten he sitten kirjoissaan suomea opettivat? Tavat poikkeavat selkeästi toisistaan: Aavikin filologinen, ikään kuin kertauskirjan omainen suomea ja viroa toisiinsa alati vertaileva opetustyyli poikkesi radikaalisti Györffyn rauhallisesti etenevästä "helposta vaikeaan" -opetustavasta. Se sopi mainiosti papiksi opiskeleville henkilöille, joilla ei myöskään välttämättä ollut mitään filologista taustaa vieraan kielen opintoihin. Molemmat annostelivat suomen kielen morfologian keskeisiä 
piirteitä - eritoten astevaihtelun opetusta - järkevällä tavalla: Aavik opetti piirteen perinpohjaisesti, Györffy tyytyi keskimääräiseen opetussisältöön. On myös huomattava, että kirjojen ilmestymisen välillä on runsaat 30 vuotta. Györffyn kirjan sisältö oli muiden aikalaisten sisältöjen kaltaista ja sisälsi selkeän suomi vieraana kielenä -opetusnäkemyksen sekä jopa jo kommunikatiivisia kysymysosioitakin. Tässä on nähtävissä selvä opetusmenetelmällinen muutos kohti nykyistä S2-opetuksen sisältöä. Aavikin kirja taas edusti aivan 1900-luvun alun kielenopetusmallia ja oli oman aikansa tuote, johon vertailukohteita hain Johannes Neuhausin tavasta opettaa suomea. Tutkitut oppikirjat olivat oman aikansa tuotteita myös sisällöllisesti.

Kielisukulaisuus näkyi tietenkin Aavikin teoksessa kautta linjan, kun taas Györffyn filologinen kompetenssi ei yltänyt enempään kielten väliseen vertailuun suomen kielen opillisen taustansa vuoksi. Mutta hänen taustansa riitti mainiosti tämän oppikirjan opetustarpeisiin.

\section{Kiitokset}

Kiitän tekstini kahta anonyymia arvioijaa.

\section{Lähteet}

Tutkimusaineiston oppikirjat

Aavik, J. 1902. Praktilik Soome keele õpetus. Helsingis: Yrjö Weilin'in kirjastus. Györffy, Béla 1939: Gyakorlati finn nyelvkönyv. Győr: Harangszó.

\section{Kirjallisuus}

Aaltio, Maija-Hellikki 1992. Finnish for foreigners 1. Helsingissä: Otava.

Alvre, Paul 1969. Soome keeleõpetuse reeglid. Tallinn: Valgus.

von Becker, Reinhold 1824. Finsk Grammatik. Åbo: Bibel-Sällskapets Tryckeri.

Béla Györffyn henkilötiedot. http://www.freeweb.hu/felpec2/hnagygyor.php (24.10.2015).

Bergh, Volmar 1940. Finsk Språklära. Grammatik med text och ordförteckning jämte översättningsövningar. Stockholm: C. E. Fritzes Bokförlags Aktiebolag. 
Bessonoff, Salli-Marja, Eila Hämäläinen 2011. Aletaan ja jatketaan! Helsinki: Suomen kielen, suomalais-ugrilaisten ja pohjoismaisten kielten ja kirjallisuuksien laitos, Helsingin yliopisto.

Bianchini, Linda 1942. Svensk-Finsk Tolkbok. Hjälpreda vid fadderskapsverksamhet och sjukvård. Andra upplagan. Stockholm: Klara Civiltryckeri.

Budenz, József 1873. Rövid finn nyelvtan (alaktan) és olvasmányok. Budapest: Kókai Lajos kiadása.

Collinder, Björn 1941. Lärobok i Finska Språket för Krigsmakten under medverkan av B. G. Geijer och H. Aikio. I. Grammatik. II. Lärokurs. Rekvireras från Lantförsvarets kommandoexpedition, Bokdetaljen Stockholm 2. Stockholm: Ivar Haeggströms Boktryckeri Aktiebolag.

Corander, Henricus Constantius 1853. Dissertatio Academica, originem indolemque qenuinam formarum linguae Fennicae verbalium enucleare periclitatura. Helsingforsiae: Typis Frenckellianis.

Elomaa, Eeva 2009. Oppikirja eläköön! Teoreettisia ja käytännön näkökohtia kielten oppimateriaalien uudistamiseen. Jyväskylä Studies in Humanities 122. Jyväskylä: Jyväskylän yliopisto.

Ekvall, Ulla 2001. Den styrda och styrande läroboken. - Björn Melander, Björn Olsson (Toim.), Verklighetens texter. Lund: Studentlitteratur, 43-77.

Englund, Robert 1942. Finsk språklära. Heidelberg: Julius Groos Verlag.

Englund, Robert 1946. Radiokurs i finska I. Tredje oförändrade upplagan. Helsingfors: Söderström \& C:o Förlagsaktiebolag.

Englund, Robert, Werner Wolf 1953. Finnische Sprachlehre. Heidelberg: Julius Groos Verlag.

Eurén, Gustaf Erik 1852. Suomalainen Kielioppi Suomalaisille. Turku: J. W. Lillja \& Co.

Fábián, István 1859. Finn nyelvtan. Pest: Emich Gusztáv nyomtatása.

Geijer, B. G., Kaarlo Nieminen 1940. Snabbkurs i Finska. Kort handledning i finska språket av B. G. Geijer, Lärare vid Kungl. Krigshögskolan jämte Kortfattad svensk-finsk parlör av Kaarlo Nieminen Lektor i finska språket vid Helsingfors universitet. Stockholm: Svenska Bokförlaget. P. A. Norstedt \& Söner.

Grünthal, Riho 2009. Suomen kielen vaikutus viron kieleen. - Jyrki Kalliokoski, Lari Kotilainen, Päivi Pahta (Toim.), Kielet kohtaavat. Tietolipas 227. Helsinki: SKS, 231-260.

Hakulinen, Auli 2008. Mitä kielioppi kertoo. - Tiina Onikki-Rantajääskö, Mari Siiroinen (Toim.), Kieltä kohti. Helsinki: Otava, 268-284.

Hakulinen, Lauri 1979. Suomen kielen rakenne ja kehitys. Neljäs, korjattu ja lisätty painos. Helsinki: Otava. 
Heikkinen, Liisa 1981. Suomenkielisen suomen kielen oppikirjan synty ja kehittyminen 1880-luvulla. Folia Fennistica \& Linguistica. Tampereen yliopiston suomen kielen ja yleisen kielitieteen laitoksen julkaisuja 4. Tampere: Tampereen yliopisto.

Hirsjärvi, Sirkka, Pirkko Remes, Paula Sajavaara 2013. Tutki ja kirjoita. 18. painos. Helsinki: Tammi.

Hunfalvy, Pál 1853. Finn és magyar szók egybehasonlitása. Pesten.

Hunfalvy, Pál 1861. Finn olvasmányok. A finn nyelvet tanulók számára. Pest: Eggenberger Ferdinánd.

Ingo, Rune 1990. Lähtökielestä kohdekieleen. Johdatusta käännöstieteeseen. Helsinki: WSOY.

ISK = Auli Hakulinen, Maria Vilkuna, Riitta Korhonen, Vesa Koivisto, Tarja Riitta Heinonen, Irja Alho 2004. Iso suomen kielioppi. Suomalaisen Kirjallisuuden Seuran Toimituksia 950. Helsinki: SKS.

Jaakkola, Hanna 1997. Kielitieto kielitaitoon pyrittäessä. Vieraiden kielten opettajien käsityksiä kieliopin oppimisesta ja opettamisesta. Jyväskylä Studies in Education, Psychology and Social Research 128. Jyväskylä: Jyväskylän yliopisto.

Järventausta, Marja 2013. Arvid Rosenqvists Lehr- und Lesebuch der finnischen Sprache: Hinter- und Beweggründe. - Marja Järventausta, Marko Pantermöller (Toim.). Finnische Sprache, Literatur und Kultur im deutschsprachigen Raum. Veröffentlichungen der Societas Uralo-Altaica 85. Wiesbaden: Harrassowitz, 91-112.

Kállay, Ferencz 1844. Finn-magyar nyelv. Pesten: Landerer és Heckenast.

Kallio, Aukusti Herman 1887. Finsk Elementarbok. I. Andra, omarbetade upplagan. Borgå: Werner Söderström.

Kallio, Aukusti Herman 1890. Suomen kielioppi. Ensimmäistä alkeisopetusta varten. Helsinki: SKS.

Kallio, Aukusti Herman 1904. Suomenkielen Alkeiskirja. II. Neljäs painos. Finsk Elementarbok. II. Fjärde upplagan. Helsingfors: Söderström \& C:o.

Karanko, Outi, László Keresztes, Irmeli Kniivilä 1990. Finn nyelvkönyv haladóknak. Budapest: Tankönyvkiadó.

Karlsson, Fred 1983a. Suomen peruskielioppi. 2. painos. Suomalaisen Kirjallisuuden Seuran toimituksia 378. Helsinki: SKS.

Karlsson, Fred 1983b. Suomen kielen äänne- ja muotorakenne. Helsinki: WSOY.

Karlsson, Fred 2000. E. N. Setälä vaarallisilla vesillä. Tieteellisen vallankäytön, käyttäytymisen ja perinteen analyysi. Suomalaisen Kirjallisuuden Seuran toimituksia 765. Helsinki: SKS. 
Karlsson, Fred 2009. Suomen peruskielioppi. Neljäs, laajennettu ja uudistettu painos. Suomalaisen Kirjallisuuden Seuran toimituksia 378. Helsinki: SKS.

Kieli ja sen kieliopit: opetuksen suuntaviivoja. Helsinki: Opetusministeriö, 1994.

Koranteri, H. K. (toim.) 1845. Suomalainen kieli-oppi koulujen tarpe’eksi. Ensimmäinen osa. Ruotsalaisen esipuheen kanssa opettajille. Wiipuri: Johanna Cedervallerin ja pojan tykönä.

Koskinen, Irina 1988. Hyvästit kieliopille. Äidinkielen kielioppi suomenkielisessä oppikoulussa ja kansakoulussa vuoden 1843 koulujärjestyksestä peruskoulu-uudistukseen. Helsingin yliopiston opettajankoulutuslaitos. Tutkimuksia 67. Helsinki: Helsingin yliopisto.

Kuukka, Katri, Minna Muukkonen, Aurora Vasama, Marjut Vehkanen 1999. Meidän suomi. Helsinki: Otava.

Kuukka, Katri, Minna Muukkonen, Aurora Vasama, Marjut Vehkanen 2011. Meidän suomi. 2.-6., tarkistettu painos. Helsinki: Otava.

Laatikainen 1940 = Э. П. Лаатикайнен. Учебник финского языка ['Suomen kielen oppikirja']. Петрозаводск: Государственное Издательство Карело-Финской ССР.

Laihiala-Kankainen, Sirkka 1993. Formaalinen ja funktionaalinen traditio kielenopetuksessa. Kielenopetuksen oppihistoriallinen tausta antiikista valistukseen. Jyväskylä Studies in Education, Psychology and Social Research 99. Jyväskylä: Jyväskylän yliopisto.

Laine, Tuija 2002. Kirkossa, kaupungissa, kolhoosissa. Suomalaisten aapisten arvoista Agricolasta 1960-luvulle. - Inkeri Pitkäranta (Toim.), ABC Lukeminen esivallan palveluksessa. Kansalliskirjaston Gallerian julkaisuja 2. Helsinki: Helsingin yliopiston kirjasto, 79-132.

Lehmann, Ellis, Annikki Torp 1951. Finsk sprogfører. København: Jespersen og Pios Forlag.

Leiponen, Elviira 2000. Suomen kieli. Petroskoi: Karjala.

Lepäsmaa, Anna-Liisa, Leena Silfverberg 1998. Suomen kielen alkeisoppikirja. 6., uudistettu painos. Helsinki: Oy Finn Lectura Ab.

Långström, Sture 1997. Författarröst och lärobokstradition. En historiedidaktisk studie. Institutionen för svenska \& samhällsvetenskapliga ämnen. Umeå: Umeå universitet.

Martin, Maisa 1995. The Map and the Rope: Finnish Nominal Inflection as a Learning Target. Studia philologica Jyväskyläensia 38. Jyväskylä: University of Jyväskylä.

Neuvonen, Eero K. 1935. Éléments de Finnois. Textes, grammaire, vocabulaire première année. Helsinki: SKS. 
Neuhaus, Johannes 1919. Kleine Finnische Sprachlehre nebst einem Wörterverzeichnis der finnisch-indoeuropäischen Entlehnungen von Johannes Neuhaus, Lektor des Neunordischen an der Universität Berlin. Zweite Auflage. Heidelberg: Julius Groos Verlag.

Nuutinen, Olli 1996. Kielen oppikurssin laatiminen. - Marjut Vehkanen (Toim.), Suomi toisena/vieraana kielenä. Ajatuksia kielestä, kulttuurista, metodeista. Helsinki: Edita, 11-18.

Pesonen, Sari, Marjut Vehkanen 2016. Finskan. Lättare än du tror. 6., uusittu painos. Helsinki: Edita.

Petraeus, Aeschillus Olai 1649. Linguae finnicae brevis institutio, exhibens vocum flectiones per casus, gradus \& tempora, nec non partium indeclinabilium significationem, dictionumq[ue] constructionem \& prosodiam. Ad usum accommodata. Aboae: imprimebat Petrus Wald.

Remes, Hannu 2010a. Johannes Aavik ja Juhani Aho. - Kirjallisuudentutkimuksen aikakausilehti Avain 4, 58-67.

Remes, Hannu 2010b. Johannes Aavik viron kielen sanaston kehittäjänä. - Tuglasseuran esitelmä 10.2.2010 (kopio).

Richards, Jack C., Theodor S. Rodgers 2001. Approaches and Methods in Language Teaching. Second edition. Cambridge: Cambridge University Press. https://doi.org/10.1017/CBO9780511667305

Riihonen, Harald (toim.) 1929. Lukukirja ja sanasto suomenkielen opiskelijoille. Leningrad: Kustannusosuuskunta Kirja.

Sajavaara, Kari 1999. Kontrastiivinen tutkimus ja virheanalyysi. - Kari Sajavaara, Arja Piirainen-Marsh (Toim.), Kielenoppimisen kysymyksiä. Jyväskylä: Soveltavan kielentutkimuksen keskus, 103-128.

Salokangas, Raimo 2003. Itsenäinen tasavalta. - Seppo Zetterberg (Toim.), Suomen historian pikkujättiläinen. Helsinki: WSOY, 678-686.

Sebeok, Thomas A. 1947. Spoken Finnish. Book one. USA: The Linguistic Society of America and the Intensive Language Program of the American Council of Learned Societies.

Setälä, E. N. 1880. Suomen kielen lause-oppi: oppikirjan koe. Helsingissä: Holm.

Suni, Minna 2008. Toista kieltä vuorovaikutuksessa. Kielellisten resurssien jakaminen toisen kielen omaksumisen alkuvaiheessa. Jyväskylä Studies in Humanities 94. Jyväskylä: Jyväskylän yliopisto.

Szinnyei, József 1895. Finn olvasókönyv mondattani példatárral. Budapest: Hornyánszky Viktor kiadása.

Szinnyei, József 1916. Finn Olvasókönyv. Nyelvtani példatárral. Finnugor Kézikönyvek. II. Ötödik kiadás. Budapest: Hornyánszky Viktor kiadása. 
Syväoja, Hannu 2004. Kansakoulu - suomalaisten kasvattaja. Perussivistystä koko kansalle 1866-1977. Jyväskylä: PS-kustannus.

Tanner, Johanna 2012. Rakenne, tilanne ja kohteliaisuus. Pyynnöt S2 -oppikirjoissa ja autenttisissa keskusteluissa. Helsinki: Helsingin yliopisto, Suomen kielen, suomalais-ugrilaisten ja pohjoismaisten kielten ja kirjallisuuksien laitos.

Tuomi, Jouni, Anneli Sarajärvi 2013. Laadullinen tutkimus ja sisällönanalyysi. 10., uudistettu painos. Helsinki: Tammi.

Tuomikoski, Aune, Helen Deans 1952. Elementary Finnish. Texts, Grammar, Glossary. (Translated and adapted from Eero K. Neuvonen's Éléments de Finnois.) Helsinki: SKS.

Vehkanen, Marjut 2015. Kieliopista kommunikaatioon. Suomi toisena ja vieraana kielenä -oppikirjat vuosina 1866-1953. Helsinki: Unigrafia Oy.

Vhaël, Bartholdus G. 1733. Grammatica fennica. Aboæ: Excud. Johan Kiämpe.

White, Leila 1993. Suomen kielioppia ulkomaalaisille. Helsinki: Oy Finn Lectura $\mathrm{Ab}$.

Vihonen, Sakari 1978. Suomen kielen oppikirja 1600-luvulla. Kieliopillinen ajattelu 1600-luvun suomenkielen oppikirjoissa. Studia Philologica Jyväskyläensia 11. Jyväskylä: Jyväskylän yliopisto.

Wiik, Kalevi 1989. Suomen kielen morfologian historia I. Nominien taivutus 1649-1820. Turku: Turun yliopisto.

Voutilainen, Eero 2012. Kielioppi. - Vesa Heikkinen, Eero Voutilainen, Petri Lauerma, Ulla Tiililä, Mikko Lounela (Toim.), Genreanalyysi - tekstilajitutkimuksen käsikirja. Kotimaisten kielten keskuksen julkaisuja 169. Helsinki: Gaudeamus, 55-58. 


\title{
Two ways of teaching Finnish as a foreign language - Praktilik Soome keele õpetus by Johannes Aavik (1902) and Gyakorlati finn nyelvkönyv by Béla Györffy (1939)
}

\author{
MARJUT VEHKANEN \\ University of Helsinki
}

In this paper I have made comparisons between two old textbooks of Finnish as a foreign language. My conclusions will shed more light on the variety of the contents in these textbooks.

The first of the books, Johannes Aavik's textbook for Estonians, Praktilik Soome keele õpetus ('A practical textbook of Finnish') has been written at the beginning of the 20th century (1902). The method of teaching used in the book was to compare the Estonian and Finnish languages in order to find the similarities and differences between these two Finnic languages. The second book, Béla Györffy's Gyakorlati finn nyelvkönyv ('Practical Finnish textbook') was published in Hungary more than 30 years later (1939), and in it one can already see clear signs of the grammar-translation method and even attempts to develop communicative competence. Both books are products of their time: the Finnish language is taught with a method used in teaching at that particular time. Both books focus on grammar and explain it in the mother tongue of the students (Estonian or Hungarian).

Keywords: L2-grammar teaching; pedagogical solutions of L2-textbooks; Estonian and Hungarian as L1; Finnish as L2

\author{
Marjut Vehkanen \\ Helsingin yliopisto \\ Suomen kielen, suomalais-ugrilaisten ja pohjoismaisten kielten \\ ja kirjallisuuksien laitos \\ Runeberginkatu 39 A 46 \\ 00100 Helsinki, Finland \\ marjut.vehkanen@gmail.com
}

